\title{
Benzodiazepines: Taking the Good with the Bad and the Ugly
}

\author{
By Jack M. Gorman, MD
}

A friend of mine recently told me a telling analogy concerning benzodiazepines (BZs). I am not sure if he wants to be publicly acknowledged for his quip. He said, "Prescribing benzodiazepines is like watching pornography. If you ask a person at random if he watches pornography, he will vehemently deny it, but someone must be because it is a billion dollar a year business. Similarly, if you ask a physician if he prescribes Valium or Xanax or Ativan [forgive my uncharacteristic use of brand names, but the story loses its impact otherwise], he or she will say of course not, what sensible doctor would prescribe those addicting drugs. Yet, like pornography, benzodiazepine prescriptions generate billions of dollars of revenue around the world, so somebody must be prescribing them."

As our outstanding guest editor, Nancy A. Ator, $\mathrm{PhD}$, of Johns Hopkins University School of Medicine, notes in her introduction to this month's CNS Spectrums, $\mathrm{BZs}$ were once heralded as a virtual answer to a prayer. Prior to their discovery, we prescribed barbiturates and meprobamate for anxiety, drugs of arguable efficacy and undeniable risk. BZs were seen in the 1960s and 1970s as safe and reliable. By 1977, diazepam was the most commonly prescribed medication in the United States, with some countries in Western Europe even more avid consumers. Then, as seemingly inevitably happens in medicine, a pendulum swung with horror stories of addiction like that portrayed in the novel I'm Dancing As Fast As I Can. ${ }^{1}$ Suddenly, BZs went from safe and effective to addicting and dangerous. By the time the serotonin reuptake inhibitors were introduced, psychiatrists were convinced (at least in public discourse) that they should replace BZs as treatment for anxiety disorders in most situations; other physicians stopped prescribing them for back pain and other muscle problems; and later drugs that are technically not BZs (but nevertheless bind to the BZ receptor) like zolpidem replaced them as hypnotics.

Yet, through it all, BZs are still prescribed and at least two pharmaceutical companies have attempted to corner the market with sustained-release preparations. Why are drugs so seemingly notorious still so often prescribed? The truth is that benzodiazepines are hard to beat. Very few medications work so reliably for their target conditions. It is a rare, anxious patient that real- izes no benefit from taking a BZ. Most patients tolerate them well and they are not fatal in overdose. Even the lore that combinations of BZs and alcohol in excess can cause acute cardiorespiratory collapse and death are actually not supported by any convincing data. The risk of dependence and serious withdrawal effects scares many clinicians and patients, but in an era when managed pharmaceutical companies virtually demand that we prescribe medications in 90-day supply and psychiatric guidelines call for longer and longer periods of treatment for mood and anxiety disorders, it is hard for a clinician to muster concern for long-term risks. Thus, there is something very useful about benzodiazepines and rather than trying to find substitutes, none of which have yet proven to really do what BZs do, science is turning toward trying to build a better BZ.

The articles in this issue of CNS Spectrums demonstrate several important points about neuropharmacology. First, BZs are probably the only class of psychoactive medications for which we are pretty certain that we understand the mechanism of action. We know some things about what antidepressants do, like blocking the presynaptic reuptake of neurotransmitters, but whether those have anything to do with how they relieve depression is entirely unclear. Similarly, antipsychotics block the dopamine $\mathrm{D}_{2}$ receptor, but who knows if this is really the reason they diminish positive symptoms of psychosis. And which of the multitude of actions of many of the new anticonvulsants is really the mechanism that imparts anticonvulsant effects? But for BZs, we are nearly certain that potentiating the effects of $\gamma$-aminobutyric acid (GABA) in opening the chloride ionophore on the $\gamma$-aminobutyric acid type $\mathrm{A}\left(\mathrm{GABA} \mathrm{A}_{\mathrm{A}}\right)$ receptor to hyperpolarize neurons throughout the central nervous system is almost certainly the direct mechanism of anti-anxiety action.

Second, tinkering with the structure of drugs that bind to $\mathrm{GABA}_{\mathrm{A}}$ receptors by manipulating subunitspecific binding represents one of the most fascinating attempts to use what we know from molecular neuroscience to follow a rational route to psychotropic drug development. It is still unclear whether these attempts will be clinically successful, but the opportunity to use basic science to guide neuropsychopharmacology is a welcome new trend.

Dr. Gorman is the editor of this journal and Esther and Joseph Klingenstein Professor of Psychiatry and chair of the Department of Psychiatry at Mount Sinai School of Medicine in New York City. 
The articles from this issue were mostly gleaned from talks given as part of a symposium chaired by Dr. Ator and myself at the annual meeting of the American College of Neuropsychopharmacology.

In addition, David J. Nutt, MD, PhD, a leading psychopharmacologist and biological psychiatrist from the United Kingdom, reviews medication treatments for anxiety disorders. Taken together, these articles provide fine insights into the rapidly changing panorama of anti-anxiety medication practice and research.

And speaking of changing panoramas, we are once again welcoming a new year. This gives me the opportunity to thank a number of people with whom I work with closely in bringing you CNS Spectrums. Darren Brodeur, our publisher, has once again made major gains in bringing the journal to the attention of a broad international community and all of us who care about psychiatry, neurology, and neuroscience are grateful to him for giving us this voice throughout the world. My fellow editors, Eric Hollander, MD, and Joseph Zohar, $\mathrm{MD}$, are also close friends and colleagues who work diligently to find and perfect the best articles for the journal, as do our stellar group of international editors and editorial board members. I particularly wish to thank Shoshana Bauminger and José Ralat, the editorial staff members at MBL Communications, Inc. who are dedicated to CNS Spectrums.

Finally, I want to take this opportunity to thank all of our "anonymous" peer reviewers for 2004. We take the peer review system extremely seriously at CNS Spectrums and those of you who have devoted your time to make it work are of utmost importance.

We will have more great issues and events in 2005, so stayed tuned. CNS

\section{REFERENCE}

1. Gordon B. I'm Dancing as Fast as I Can. New York, NY: Harper \& Row; 1979.

\section{We would like to thank the following peer reviewers who contributed to CNS Spectrums in 2004:}

Adekola Alac, MI)

Stephen Aronson, MD

Robert A. Baker, PhI)

Claudia Baldassano, MI)

[)avid H. Barlow, PhD)

(arl Bazil, MD), PhI)

Badreddine Bencherif, MI)

()) avid Biegel, MI)

Antonia Bifulco, ['hD)

Timothy I). Brewerton, MI)

Robert W. Buchanan, MI)

Peter F. Buckley, MD)

Vivien K. Burt, MI), PhI)

Kristin S. (adenhead, MI)

Peter (árlen, MI), FRCPC

Williatn T. (arpenter, Jr., MI)

Charles (artwright, MD)

Dorothy M. Castrille, PhD)

Donna T. (hen, MI), MPH

Dehorah S. Cowley, MD

Sostt (row, ML)

(aroline Davis, l'hD)

Melissa I?. DelBello, MD)

Marc Dichter, MD, PhI)

Richard Drake, MRCPsych, PhD

Juseph Drazkowski, MD)

[avid W. Dunn, ML)

[avid L. Dunner, MD

Dennis (3. Dyck, Phl)
Giuseppe Erba, MI) Beatrice Files, MD

Mats Fredrikson, PhD

Marlene Freeman, MD

Christopher Frueh, $\mathrm{PhD}$

Jason C.G. Halford, PhD,

C.Psychol

Stephan Hamann, PhD

Benjamin L. Handen, $\mathrm{PhD}$

Michel Hansenne, PhD

W. Allen Hauser, MD)

Dirk H. Hellhammer, MD

Calvin J. Hobel, MD

Rudolf Hochn-Saric, MD)

William Horan, PhD

Rebecca Ichord, MD

Vijeya Ganesan, MD

Alan J. Gelenberg, MD

Frank Gilliam, MD, MPH

Shirley M. Glynn, PhD

Terry Goldherg, PhD

Sam Goldstein, PhD

Michael Gordon, PhD

John H. Griest, MD)

Leon Grunhaus, MD

Philip G. Janicak, MD

Richard Keefe, PhD

Mihcelle L. Keightley, PhD

Robert S. Kern, PhD
Bryan $\mathrm{H}$. King, $\mathrm{MD}$ )

Harry R. Kissileff, PhD

Haim Y. Knobler, MD)

Scott Kollins, PhD

Gregory Krauss, MD

Bryan Lask, MD

Todd Lencz, PhD

Jean-Pierre Lindenmayer, MD

Leopold Liss, MD

Edythe London, $\mathrm{PhD}$

John Kylan Lynch, MD

Rajnish Mago, MD

Andres Martin, MD, MPH

Alexandra McBride, MD

Christopher J. McDougle, MI

Thomas H. McGlashan, MI)

Richard S. McLachlan, MD,

FRCPC

Richard McNally, PhD

David J. Miklowitz, PhD

Del D. Miller, PharmL), MD

James E. Mitchell, MD

Kim Mueser, MD

Ulrike Nowak-Göttl, MD

David J. Nutt, MD, PhD

Michael W. O'Hara, $\mathrm{PhD}$

J. Gregory Olley, PhD

Maria Oquendo, MD

Thomas Owley, MD
George I. Papakustas, MD)

Martin P. Paulus, PhI)

Mani N. Pavuluri, MI), PhD

Neelan Pillay, MI)

Mark H. Pollack, MD

Nunzio Pomara, MI)

Charles Popper, MI)

Thomas A. Posever, MI)

David J. Posey, MI)

James B. Potash, MI), MPH

Enest Quimhy, $\mathrm{PhI}$ )

Isabelle Rapin, $\mathrm{MD}$

Charles A. Rapp, PhD

Scott L. Rauch, MI)

Avi Reichenherg, Phl)

William E. Reichman, MI)

Margaret A. Richter, MI)

Sally J. Rogers, PhI)

Richard N. Rosenthal, MD

Richard Rosse, MI)

Stephanie Rosser, M. Psychol (Clin.)

Bryan Roth, MD, PhD

Barbara O. Rothbaum, PhD)

Marc-André Roy, MI), MSc

(épidémiologie), FRCP

Peter P. Roy-Byrne, MD)

Peter G. Rumney, MI), FRCPC

Mary Rutherford, MD
Tetsuya Sato, MI), ['hl)

Sinjaya Saxena, MI)

Russell Sichachar, MI), FRC ITC

Thomas L. Schwartz, MI)

Mary V. Seemuan, ML)

Larry J. Seidman, MI)

Mark Sergi, [hl)

Alessandru Sierretti, MI)

Andrew Shaner, MI)

Kenny J. Simansky, Phl)

Nizomi M. Simon, MI)

(Clindio N. Surare, MI), I'hl)

James J. Stiudenmeier, MI ), MIPH

Mark A. Stein, $\left.\mathrm{M}_{1} \mathrm{~L}\right)$

P. Antonio Tataranni, Ml)

(iregury B. Teigue, P'hl)

Mathukar H. Trivedi, MI)

James W. Varni, I'hl)

Jeremy Veenstra-Vinder

Wed, ML)

Shigeto Yamawaki, MI), ('hl)

Myron A. Waclawiw, l'hl)

Peter Weiden, MI)

Margaret W(ciss, Ml), Phl)

Blake W(x)dside, ML)

Alison R. Yung, MI), MBRS, MPM, FRANZCI 